\title{
1. A critical overview of religion, culture and consumption in developing nations
}

\author{
Ayantunji Gbadamosi
}

\section{INTRODUCTION}

Religion is an enigma. It is interestingly complex in that it has a global relevance in various ways. It is closely interlocked with many other phenomena such as politics, ethics, culture, and consumption. Relating it to consumption specifically opens up a number of spectacular avenues for discussion. In the marketing parlance, consumption is presumably related to every individual and consumer segment in one form or another. It applies to old as well as the young, rich and the poor, various educational categories, all geographical locations, and in various seasons, to mention but a few cases. For instance, while the Covid-19 pandemic may have changed consumption patterns of many households as a specific phase of humanity, it does not in any way remove the discourse outright.

Meanwhile, in a somewhat related way, the discourse of religion is wide-ranging. Those who are not affiliated to any religion have reasons for their stance and their religiosity as well as reasons for such a disposition to make the explication of religion to consumption very intriguing. The interrelated nature of both religion and consumption indicates a varying dynamic of consumer behaviour in different contexts. Hence, it is judicious to show interest in developing countries as a context rather than having a broad and overly generalised focus on the subject. Such undue generalisation will constrain the extent of meticulosity that could be applied to studying the nitty-gritty of such an important phenomenon. Meanwhile, nations are categorised on the basis of their economic conditions. Broadly speaking, countries are categorised as developed economies, developing countries, and economies in transition (UN, 2013). Statistically, one of the commonly used indicators of the economic position of nations is gross national income (GNI). Hence, for the year 2020, the low-income economies are noted as those countries with a GNI per capita 
of no more than $\$ 1,025$ in 2018 , while those with a GNI that ranges between $\$ 1,026$ and $\$ 3,995$ are categorised as falling into the lower middle-income category, and those regarded as upper middle-income economies are characterised by a GNI of between \$3,996 and \$12,375 (World Bank, 2020). Accordingly, and as stated in the same source, those with more than $\$ 12,375$ GNI are known as high-income economies (World Bank, 2020). In addition to the statistical calculation, another useful indicator of developing countries which will give us a more qualitative understanding of the context and serve the operational definition of the term is to define such countries as those with a GNI lower than those of developed countries. Besides, some of the common characteristics of developing economies have been shown as low per capita income, overpopulation, high unemployment rate, high level of illiteracy, low level of technological development, and people tend to be caste-minded and religious (Knowledge Team, 2017). Hence, cases and illustrations will be drawn from this context to discuss the interactions of religion and consumer behaviour. This chapter, which sets the pace for others in this book, covers a number of key issues including emerging issues in contemporary consumer behaviour, the consumer decision-making process, main influences on consumer behaviour, and a critical overview of culture and religion. Other issues addressed in the chapter are religion and consumption in developing nations as well as the dynamics of this consumption pattern in the twenty-first-century developing nations.

\section{CONTEMPORARY CONSUMER BEHAVIOUR AND THE EMERGING ISSUES: A CRITICAL OVERVIEW}

Consumer behaviour has been considered an interesting phenomenon from different perspectives. Whether we consider it from the perspective of the consumers whose behaviour is the focus in the discourse or from the viewpoint of business organisations that use the knowledge for decision making, it remains a fascinating issue. In summing up, Asem (2018) describes it as involving identification, consumption, and the removal of products and services as well as the processes that give rise to these actions and those following them. This perspective is elaborate and aligns very well with several other contributions on this subject such as those offered by Hoyer et al. (2018), Babin and Harris (2018), Solomon (2018), and Schiffman and Wisenblit (2019). Hence, it could be a good platform upon which the discussion in this segment and the chapter could be based. Consumer behaviour as a phenomenon is even more interesting when considering the discourse in relation to the contemporary consumer who is awash with choices and strategies for fulfilling her needs. This is the point made by Singhal (2018), who indicates that the consumer of today is confronted with the dilemma of gauging the balance between the risks and 
benefits of innovation. As indicated in the literature, we experience innovation every day. The food we eat and the mode of serving it, the fashion items we use for different occasions, the automobile we use in various ways, and services of various professionals are some of the areas in which we can see pointers of the innovative developments in society in recent times. Similarly, our experiences in the gig economy have taken the contemporary consumption story to a whole new level far above the traditional terrain. We react to these innovations differently in that some are enthusiastic about the new technological breakthrough while others are not (Singhal, 2018). For instance, one category of consumer will not only be willing to pay a premium to acquire a new invention but will also willingly stay in the queue to be among the first set of consumers that will get the product on the same day it is launched. Conversely, another group could show no interest at all in new market offerings as they are considered to be risky in various ways (economically, socially, physically, or in other ways) due to their newness. It is therefore not surprising that having a good knowledge of consumer behaviour is sine qua non to successful business practice in the contemporary competitive marketing environment (Shaw et al., 2017).

The interest in consumer behaviour is not only applicable to the process associated with the acquisition and consumption of goods and services but also in the disposition of products. So, issues around recycling and reusage are becoming more and more relevant to the discourse of consumerism. Ting et al.'s (2019) study on the disposition of smartphones in an emerging economy provides some insight into this interesting area. The study focuses on students in a developing country and finds that product attachment and compatibility are key influencing factors in such decisions. Specifically, they noted that students are strongly connected to their smartphone until the point when it breaks or loses compatibility. They indicate that the decision to dispose of the smartphones is not linked to the price paid for it or the brand of the phones. This study which revolves around Malaysia as a developing country challenges the conventional understanding that places undue emphasis on prices and brands as core factors in consumption dynamics. It underscores the increasing relevance of not only studying consumer behaviour in a contemporary context but also in different research contexts such as developing nations, and exploring relevant influencing factors that underpin the decisions such as the key role of religion.

\section{Consumer Decision-Making Process: Emerging Issues}

Exploring consumer behaviour as a process beginning with need recognition all the way to post purchase evaluation has been a popular discussion in marketing literature. Although the detailed discussion of this in relation to religion in developing countries is presented in Chapter 4, this segment simply teases 
out the emerging issues in the subject towards presenting a robust foundation for the phenomenon addressed in this book.

Something so fundamental about consumer behaviour is the need which also by implication indicates that the stage of need recognition is essential. This is the stage where the gap between the current state and the desired state of the consumer becomes highlighted. Our needs in life are diverse and vary in many ramifications. The need for the basic essentials of life like food and water is considered crucial. There is also the need for products that bring us close to others, usually discussed as social needs. There are a good number of studies around consumers' needs such as Maslow (1943), Adams (1963), McClelland (1978); these are some of the studies that emphasise the diversity of our needs as discussed in different contexts. For example, it could be argued that consumers in different cultural contexts could exhibit different types of needs. The specific factors that differentiate developing countries from developed ones could also be reasons to account for differences in their needs. Hence, consumers' needs in developing countries such as Malaysia, Nigeria, Ghana, Mexico, and the Philippines could be dissimilar to those in developed countries like the United States, United Kingdom, Canada, and France. Some of these needs are linked to taboos, ceremonies, and sacrifices as emphasised by Rihtaršič and Rihtaršič (2017) in their paper on the model of consumer behaviour with a focus on feminine hygiene.

In a bid to satisfy the identified needs, consumers explore various sources of information that could give them details around products and services market offerings that could be used to solve the identified problems. These sources could be commercial or non-commercial. More often than not, marketers provide information about products and services to make favourable mention of their offerings. Hence, such details around product suitability and functionality are embedded in marketing communication messages in the form of advertising, sales promotion, publicity and public relations, personal selling, and direct marketing. Also, the increasing use of digital technology has widened the sources of commercial messages for consumers. The internet usage in the world has seen a significant increase in recent times as the figure is given as 4.65 as at May 31, 2020 (Internet World Stats, 2020). As shown in this source, this represents a 59.6 per cent penetration rate for the entire population. This could help in a number of ways to provide some crucial details that could help consumers concerning the likelihood of usefulness of products or services to consumers. Nonetheless, given that there is a limit to the usefulness of the information obtained by consumers from these sources, they often find non-commercial sources of information handy. These include sources such as family, friends, co-workers, government agencies, and non-governmental organisations. Given the typical close ties within the family systems in most of the developing countries, this is an interesting explanation that will be vital 
to decisions within these societal systems. In Hofstede's national cultural typology, the notion of collectivism fits this scenario. An example of this is the notion of Umbutu which was explained as indicating that it is society that emphasises the existence of an individual. As explained in Kruger et al. (2009: 161), it is an African term which means 'my humanity is bound to your humanity', meaning 'one'. This plays a key role in how people share information on purchases and consumption activities. Since these sources do not have commercial motives, they tend to have more credibility than commercial sources.

At the stage of evaluation of alternatives, consumers screen the options available in relation to the applicable criteria. A good number of criteria could be used, depending on the nature of the products. For example, fuel efficiency, price, and comfort could be used for the selection of cars, while location, price, and closeness to amenities could be the criteria for the selection of houses. Apart from the nature of the product, the context where decisions are being made such as developed nations versus developing nations could influence or distinguish the criteria that consumers use to evaluate the appropriateness of the products or services to be selected. Religion and culture that constitute the key elements of this book could also be the key criteria. For instance, more often than not, what to eat and what to wear are influenced by religious values. Religion is increasingly becoming a defining factor in people's choices of goods and services in recent times. Further details about this are discussed later in the chapter.

The stage of decision making is fundamental to this process as it is the stage where the actual selection of the market offering which emanates from the evaluation stage takes place. The dynamics of the consumption system indicating how decisions about consumptions are made tend to be different from one society to another. For example, the question of who makes the decisions could be society-related and this also changes with time. We can draw illustration on this from the notion of family-buying roles which addresses how family members interact to play the roles of initiator, influencer, gatekeeper, decider, and user of the products or services involved. The extant literature (Munroe and Munroe, 1972; Harvey et al., 2000) indicates that decision-making roles in most developing countries are played by spouses, unlike in other contexts where children's decision-making power is stronger. Interestingly, some studies have cautioned on this postulation indicating that children could also make decisions in some circumstances. A good example here is the study of Gbadamosi (2012) who argues that children in Nigeria, especially in cosmopolitan cities, are sometimes given free will to choose when the products involved are routinely consumed items such as snacks. Similarly, the notion of e-shopping also creates a twist to the issues of purchase decisions. There are indications that e-shoppers and traditional shoppers could be similar or dissimilar in how they approach their purchase decisions (Dennis et al., 2009). This 
understanding is needed for effective discussion of contemporary marketing and societal dynamics.

At the stage of post-purchase evaluation, consumers compare their experience after the use of the products with the expectations they had before buying the products. This could lead to satisfaction and dissatisfaction. The outcome of this also determines whether a repeat purchase will take place or not. Also, repeat purchase is most likely to result in loyalty to the brand or the organisation. Many factors could be useful to trigger loyalty among consumers. Fundamentally, the market offerings should satisfy the needs but one of the challenges for businesses today is that more firms are also looking into satisfying customers. Hence, additional benefits such as warranties and excellent customer service would be needed to keep customers 'locked' into a firm's transaction system. Shaw et al.'s (2017) study into Czech consumer behaviour and warranty claims found that young consumers have a positive tendency for warranty claims. Interestingly, they show more satisfaction with warranty procedure. Apart from this study which relates to specific consumer segments, providing some degree of assurance over purchases made could be significantly beneficial for both parties in a transaction. In the same vein, just as consumers use religion at the stage of evaluation to screen which item to buy and which to avoid, they also tend to use religious belief as a guide to know whether a particular market offering has provided the needed value in specific transactions. As an example, the promise of a food vendor that the items offered for sale are compliant with halal standards of practice will be expected to hold true. To discover that this was actually not the case after consumption will be greatly disappointing to such consumers and will understandably result in dissatisfaction and in some cases negative word of mouth.

\section{Consumer Behaviour: What Are the Main Influences?}

Fundamentally, a number of factors influence consumer behaviour. Broadly speaking, we can categorise them as psychological and sociological factors. The former consists of factors such as attitudes, perceptions, self, personality and self-concept, and learning. The impact of these factors could be interactive in terms of how individuals, whether based in developing nations or developed countries, make their day-to-day consumption decisions. On the other hand, the sociological factors relate to how consumers' decisions are underpinned by other people in one form or another. These are mainly reference groups, culture, social class, and family. Meanwhile, another classification which features prominently in this chapter is the categorisation into personal factors, social-cultural factors, and marketing stimuli (see Figure 1.1).

Egan and Taylor (2010), in their study on shoplifting, unethical behaviour, and personality, found that all dimensions of consumers' personality are 


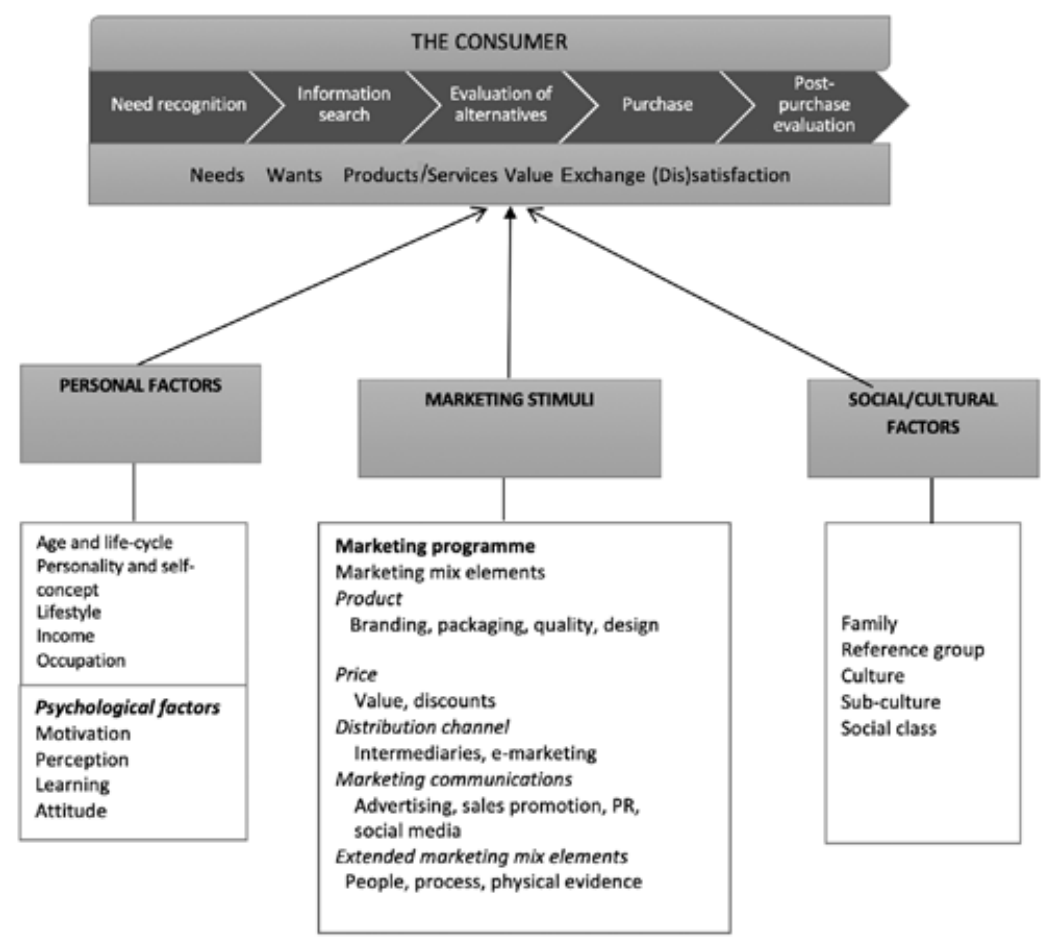

Source: Adapted from Gbadamosi (2020).

Figure 1.1 Major influences on consumer decisions

related to shoplifting and the consumer ethical belief scale. Another interesting finding in the literature is in the area of ethical consumerism, organic products, and sustainability. A study found that young students in Brno are willing to pay a premium for the freshness and better taste of organic products as well as the associated quality and are positively inclined to information relating to the moral and health issues associated with this purchase type (Švecová and Odehnalová, 2019). This is interesting to note, especially when compared to the commonly reported findings around ethical consumerism which tends to suggest somewhat different behaviour patterns from young consumers. On 
the issue of sustainability, it is reported that the motivation of consumers to embrace sustainable consumption such as switching to green electricity and limiting the use of private cars by switching to public transportation is rather limited. According to Hartmann et al. (2018), this involves costs to individuals and does not provide notable short- or medium-term personal benefits. Hence, in their study of the role of psychological empowerment in climate-protective behaviour, Hartmann et al. (2018) suggest that the behaviour of an individual in favour of the environment could be kindled by psychological empowerment which could be emphasised in various marketing messages designed to reach these consumers. So far, irrespective of the classification used, the notion of culture and religion remains core to the deeper part of the consumption system. Hence, these are now discussed in detail in the next section.

\section{CULTURE AND RELIGION: A GENERAL OVERVIEW}

As established earlier, consumption behaviour is influenced by a myriad of factors which can also be categorised in a number of ways. Meanwhile, one of the defining influences on consumption is culture. We will examine some of the interesting definitions of culture before going further into how the phenomenon is linked to religion as this intersection constitutes the focal part of this book. Culture is seen as a source of learning the symbolic system represented in the arts, aesthetics, drama, music, ritual, dance, and cosmetics by members of a society (Mansori et al., 2015). Another interesting definition of this phenomenon is the one proposed by Solomon (2020), it is seen as the personality of a particular society. Since personality is unique to an individual and specifies his or her personal being, it is understandable why this author applies this phenomenon at a wider or cultural context to indicate the specificity of that system. Meanwhile, far earlier than this, culture has been explained as the distinctive attitudes which distinguish a group of people from another (Temin, 1997). Hence, in a study on an analysis of how culture and religion affect perceived corruption in a global context, Mensah (2014) argues that viewing culture in this sense indicates that it is expressed through a variety of issues such as institutions, language, history, and religion, and both culture and religion contribute independently to the level of perceived corruption at the global level (Mensah, 2014). From the foregoing, we can infer that defining culture could be done in a number of ways. For example, we can have a definition of how it relates to an individual and how it underpins the dynamics of groups of people. This is linked to the claim that culture could be seen as the social and cognitive processes relating to individuals that underline several settings that individuals encounter in their endeavours (Abu-Nimer, 2001). A good number of scholarship effort corroborates this core role of culture in consumer behaviour. Examples include Mooij (2003), Arnould and Thompson (2005), 
Mokhlis (2006), Alam et al. (2011), Nayeem (2012), Polese and Seliverstova (2020), and Chatterjee and Mandal (2020).

Meanwhile, as can be inferred from these key highlights, there is a considerable link between religion and people's culture. So, by and large, narratives are closely related to us as people in terms of who we are, where we come from, and give cohesion to our shared beliefs of common origin identity and how this is transmitted among members (Andrews et al., 2015). This implies that narration is linked to our religions and cultures. For example, Jamal and Sharifuddin (2015) note the nature of Muslim communities to be collectivist which makes it more amenable to word-of-mouth and in-group recommendations for choices of products and services in the marketplace. Gbadamosi (2019a) notes a similar point for Christianity in his study which revolves around Pentecostalism, women entrepreneurship, and Black African consumerism in the United Kingdom. A similar pattern was noted in an earlier study (Gbadamosi, 2015). In these cases, adherents engage in solidarity with respect to consumption, business patronage, and recommendation in the form of word-of-mouth communication. This suggests that the link between religion and culture is beyond superficial.

Interestingly, with a critical review of the activities of religious faiths such as Sikhism, Islam, Hinduism, and Buddhism, it has also been pointed out that religion could be key to peace making (Cox et al., 1994; Abu-Nimer, 2001). This is closely related to the claim by Abu-Nimer (2001) that effective interfaith interactions could emphasise a number of things including ensuring that the facilitation team has the knowledge of different groups and exploring what makes each of the religions unique. For example, it has been noted that Islamic adherents are idealists who were brought up to follow a Malay philosophy that emphasises being cautious in decision making, which ensures that their actions result in fewer mistakes (Cornwell et al., 2005). Moreover, the effectiveness in interfaith dialogue would stress that scripture and sacred texts enrich this dialogue and that rituals and symbols could be useful to enhance this interaction. Also, in such interfaith dialogue, spirituality is quite significant to changing the attitudes of participants.

The study of Jamal and Sharifuddin (2015) presents a useful addition to the discourse of religion and culture in relation to food consumption. Drawing from the extant literature (Ahmed, 2008) they note that, since Islam indicates some food types to be unlawful (haram), while others are lawful (halal), businesses owned by Muslims as well as some mainstream retailers offer packaged halal food in areas with a considerable number of Muslims in the British marketing environment. This corroborates the observation noted by Winter (2006) that just as we cannot have a society without a culture, no culture exists without some form of religion. In his study that revolves around religion, culture, and the human rights of women, the issue of the Islamic headscarf, 
known as the hijab, is highlighted. Controversies surrounding this dressing mode have been documented in several places. The core arguments around these religious issues resonate with the global citizenship phenomenon which is a sense of belonging to a wider community and common humanity that embodies political, cultural, and social interconnectedness and interdependence among the local, national, and global systems (Haynes, 2019). By and large, the interplay of religion and culture comes to the fore more often than not in various societies. Meanwhile, from the perspective of Mokhlis (2009), religion and consumer behaviour are closely interlocked to the extent that it is impossible to see the influence of other factors on consumption choices.

When considering how religion impacts consumption in developing countries, it is relevant to discuss the notions of in-groups and out-groups. A seminal study on this is the work of Tajfel. With reference to Sherif (1966), it is argued in this publication that whenever members of certain groups interact with other groups, it results in in-group behaviour (Tajfel, 1982a: 2). So, members of a particular group are identified to be among the 'in-group' and people outside this are known as 'out-group'. Hence, people of a specific religious group, say Christianity, would see fellow adherents as in-group members while people outside of this religion are the 'out-group'. As indicated by Tajfel (1982a), three components of group identification can be highlighted as cognitive, evaluative, and emotional investment. According to him, the cognitive aspect revolves around members' sense of awareness of their group, whereas the evaluative element indicates that the awareness is linked to some connotations and the third emphasises the members' emotional investment in both the awareness and evaluations. This knowledge is linked to the Social Identity Theory in that social identity explains that part of an individual's self-concept which emanates from their knowledge of being members of a social group(s) (Tajfel, 1982b: 2). In the context of this book and the notion of Social Identity Theory, apart from the consumer's religiosity, the relevance of social norms associated with the religion would influence his or her choices of products and services. This explains why Shavitt et al. (2006) claim that conformity in the choice of market offerings may be unique to vertical collectivism, which emphasises deference to authority figures and the wishes of the in-group.

From a broad perspective, using medicine or healthcare consumption as the contextual platform, Hordern (2016) indicates that it is important to consider religion, belief, and culture as potential sources of personal strength and moral purpose in the healthcare system. This system encapsulates the welfare of patients vis-à-vis their experience of ill health, sufferings, healing, and dying as well as the welfare of clinicians. Hordern (2016) suggests further that it is important to consider the associated sensitivities as there could be conflict between the clinical judgement, religion, belief, and culture of an individual. As argued in this publication, it is possible for the belief of an individual to 
not be totally in alignment with his or her religion and cultural normative teachings. Hence, the dynamics should be managed without making any assumptions. This brings in the notion of religiosity. Religiosity is defined as the degree to which an individual adheres to the values, beliefs, and practices of his or her religion and uses them in daily living (Worthington et al., 2003; Jamal and Sharifuddin, 2015). This is not a radical departure from the definition of Patel (2012) which sees it as the degree to which someone is attached to a specific religious group. From the perspective of McDaniel and Burnett (1990), as cited by Mansori et al. (2015), while religious affiliation is about adhering to a particular religious group, religiosity is about the psychological and behavioural phenomenon that indicates an individual's degree of commitment and belief in specific religious values and ideals. In his study on the relevance and measurement of religiosity in consumer behaviour research, Mokhlis' (2009) findings show that religiosity has an influence on consumer behaviour in relation to factors such as price, quality, and impulse buying. Similarly, a more recent study conducted by Nasse et al. (2019) indicates a probable link between consumer behaviour and consumers' religiosity. This is an interesting finding which relates to Burkina Faso, a developing country. According to this group of authors, religion plays an important role in consumption in this country.

On the question of moral guidance and principles as embedded in religion, culture, and politics, Yagboyaju examines corruption within some of the key religious faiths in the Nigerian context. He traces corrupt practices to the disobedience of Adam and Eve who ate the forbidden fruit in the Garden of Eden as indicated in Genesis 3:5-24. Nonetheless, it is noteworthy that the Holy Bible underscores penitence and retribution for immoral and corrupt practices (Yagboyaju, 2017). He positions this discourse within the lens of the Pentecostal movement in Nigeria, in which churches speak to the material and spiritual needs of the people with a promise of life-changing breakthroughs and miracles. This tends to foster multi-religious competition in relation to those who believe this and fuels the insatiable appetite for primitive accumulation and is closely linked to the acts of those benefiting from the corrupt system.

The African Traditional Religion is characterised by multiple practices, doctrines, and experiences. In this discourse, there is a distinction between the High God, who is the supreme being that is the creator of all things and the source of all power, and the other small gods. These are commonly held beliefs in most African countries, including Nigeria and Ghana. In this context, most of the small gods are associated with nature such as rivers, rocks, iron, lagoons, and mountains. Drawing from the extant literature such as Egberongbe (1988: 69-87) and Aiyede et al. (2011: 228-9), these religious practices have elaborate moral systems and discipline for most of the society. One example cited by Egberongbe (1988) is that of Ifa, a type of god in Yoruba, notably in the south 
west of Nigeria, which stipulates 'dos' and 'don'ts' for followers such as promoting honesty, hard work, and detesting dictatorial actions over others. For Islamic religion, Yagboyaju (2017) indicates that the faith is expected to permeate every facet of the life of adherents, and he emphasises that it is a culture that connotes a way of worship, an approach to running a business, an economic system, an approach to business management, and many other aspects of life. Hence, it hardly omits any part of human existence. In fact, the close relationship between culture, religion, and corruptions which could encourage the abuse of power by public officials is part of the reason why Yagboyaju (2017) advocates a separation of politics and religion. Logically, this explains why its impact on consumption is notably significant and enduring.

\section{RELIGION IN DEVELOPING NATIONS: PERSPECTIVE ON CONSUMPTION}

It could be argued that religion is a pervasive phenomenon with wide implications on our day-to-day decision making linking issues such as values, beliefs, ethics, and consumption as shown in Figure 1.2. Its impact is worldwide which explains why it has a wide scope. Based on an eclectic review of literature including materials from the BBC, Encyclopaedia Britannica, and the specific websites of each of the religions, Table 1.1 shows some useful details about some common religions of the world.

While so many issues remain unclear about each of the religious groups, it is clear that there are some differences in how each influences its adherents. However, it is important to state that despite the variation in people's specific values and beliefs concerning various religious faiths, the behavioural patterns of the followers and the correlation between religiosity and values are considerably consistent across monothetic religions (Mansori et al., 2015). It is indicated that religious rituals, characterised by sacredness, constitute an important factor influencing an individual and groups (Suhrke, 1971). The complexity on this becomes more pronounced when considered in relation to the contextual factors around consumer behaviour. For example, it is believed that certain factors differentiate developing nations from developed countries. The sub-Saharan African region, which constitutes an example of developing nations, is characterised by stability challenges such as poverty, lack of democracy, and ineffective institutions (Pokimica et al., 2012). These tend to reflect in the consumption of this consumer group to a great extent.

In view of this claim, there are some specific studies that have been conducted in relation to developing nations on their consumption dynamics. The study of Amine et al. (2012), which revolves around consumers' opposition motives to the modern retailing format in Tunisia, found that when compared to developed nations, consumers in this context are prone to avoid and defect 


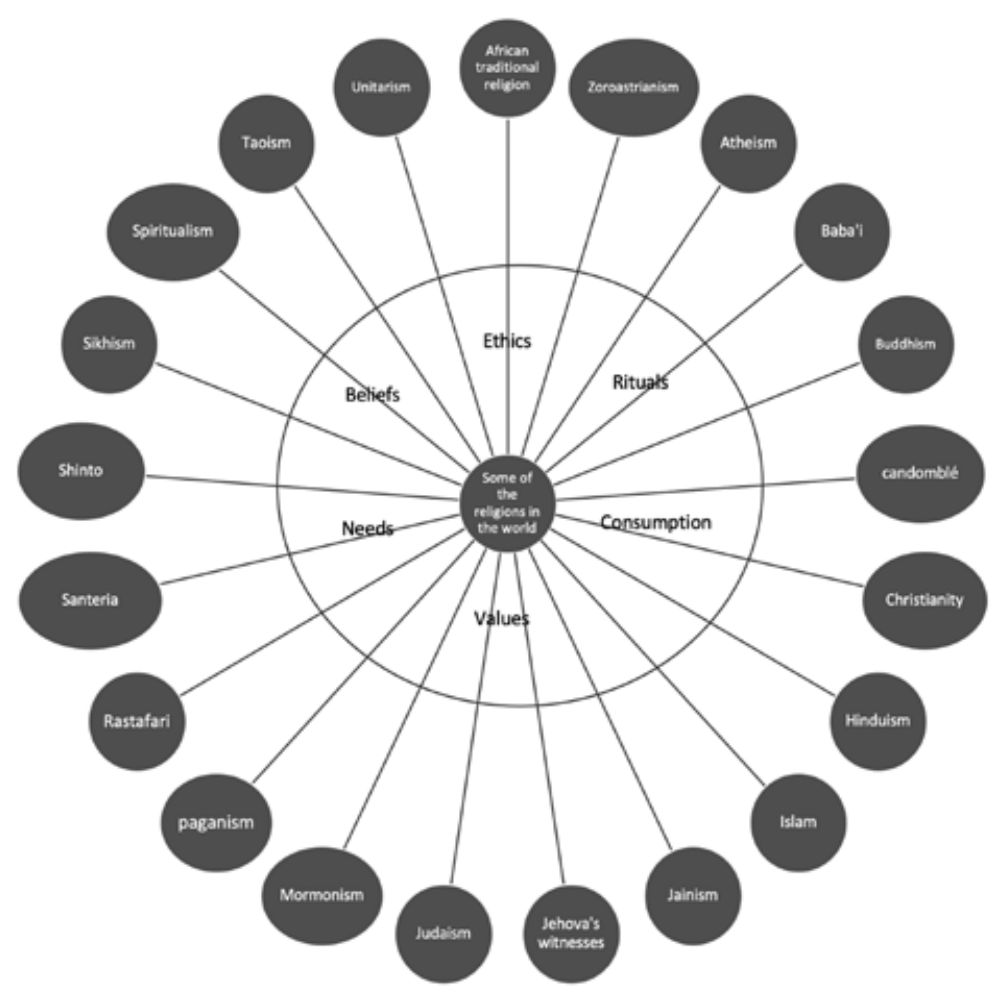

Figure 1.2 The nexus of religion and consumption: selected examples in perspective

from mass retailing. These authors indicate that this is linked to culture, education, and religion. With reference to a body of literature (Sow, 2005; Dumbili, 2013; Porter 2013), Nasse et al. (2019), whose study revolves around Burkina Faso, indicate that industrial drinks such as Coca-Cola or Fanta could be used for medical functions, food functions, and religious functions which explains their use in various events such as wedding ceremonies, funeral rites, religious rituals, and many others. Thus, consumption and religion are markedly linked as shown in this context. 
Table 1.1 Religions and their dynamics

\begin{tabular}{|c|c|c|}
\hline Religion & Basic description & Further comments \\
\hline $\begin{array}{l}\text { African Traditional } \\
\text { Religion }\end{array}$ & $\begin{array}{l}\text { Can be traced back to prehistoric } \\
\text { times. It is characterised } \\
\text { by a reliance on oral stories } \\
\text { which have been passed down } \\
\text { from generations about gods, } \\
\text { superhuman entities, and } \\
\text { ancestors. }\end{array}$ & $\begin{array}{l}\text { Followers acknowledge the existence of the } \\
\text { Supreme God who created everything and } \\
\text { other small gods. Although they do not have } \\
\text { any major doctrinal teachings, their beliefs } \\
\text { revolve around issues like the existence of } \\
\text { deities, divination, and ancestor veneration. }\end{array}$ \\
\hline Atheism & $\begin{array}{l}\text { Those following this religious } \\
\text { stance are known as Atheists, } \\
\text { and hold that God or gods are } \\
\text { man-made ideas. }\end{array}$ & $\begin{array}{l}\text { Adherents have no relationship with God or } \\
\text { any other gods. }\end{array}$ \\
\hline Baha'i & $\begin{array}{l}\text { Founded in the nineteenth } \\
\text { century by Bahá'u'lláh. }\end{array}$ & $\begin{array}{l}\text { Emphasises that human kind be united } \\
\text { spiritually. }\end{array}$ \\
\hline Buddhism & $\begin{array}{l}\text { A way of living based on } \\
\text { the teachings of the founder, } \\
\text { Siddhartha Gautama. }\end{array}$ & $\begin{array}{l}\text { Uses an understanding of cause and effect } \\
\text { through the use of practical approaches } \\
\text { like meditation for gaining insight towards } \\
\text { achieving enlightenment. It focuses on } \\
\text { shaping future through thought, actions, and } \\
\text { words. }\end{array}$ \\
\hline Candomblé & $\begin{array}{l}\text { Its root could be traced back to } \\
\text { the slave trade and it originated } \\
\text { in Brazil. }\end{array}$ & $\begin{array}{l}\text { This is a combination of elements of } \\
\text { Catholicism and some aspects of Indigenous } \\
\text { African religion and focuses on the belief of } \\
\text { a supreme creator as well as several minor } \\
\text { deities. It holds that everyone has their deity } \\
\text { that serves to protect them and guide their } \\
\text { destiny. }\end{array}$ \\
\hline Christianity & $\begin{array}{l}\text { The world's biggest faith, with } \\
\text { a focus on the teachings of Jesus } \\
\text { Christ. }\end{array}$ & $\begin{array}{l}\text { As indicated on the Christianity.org website, } \\
\text { Christianity should not be equated with going } \\
\text { to church but is about having a relationship } \\
\text { with God. It revolves around acknowledging } \\
\text { the fact that Jesus died for the sins of the } \\
\text { world. Hence, the religion is known as 'Good } \\
\text { News' in that trusting in Jesus Christ makes } \\
\text { it possible for anyone to have a relationship } \\
\text { with God. }\end{array}$ \\
\hline Hinduism & $\begin{array}{l}\text { A collection of faiths entrenched } \\
\text { in the religious ideas of India. }\end{array}$ & $\begin{array}{l}\text { Hinduism revolves around a belief in } \\
\text { reincarnation. It emphasises following } \\
\text { righteousness through spiritual practices, } \\
\text { called yogas, and prayers which are also } \\
\text { known as bhakti. }\end{array}$ \\
\hline
\end{tabular}




\begin{tabular}{|c|c|c|}
\hline Religion & Basic description & Further comments \\
\hline Islam & $\begin{array}{l}\text { Revealed in its final form by } \\
\text { the Prophet Muhammad, in the } \\
\text { seventh century CE. }\end{array}$ & $\begin{array}{l}\text { The followers of Islam are called Muslims } \\
\text { and believe in only one God, translated } \\
\text { as Allah in Arabic. They believe that God } \\
\text { sent many prophets to provide direction } \\
\text { on how to live and the final Prophet was } \\
\text { Muhammad. They believe that there are five } \\
\text { pillars of Islam, namely, declaration of faith } \\
\text { that there is no other God apart from God and } \\
\text { Mohammed is his messenger (Shahadah), } \\
\text { praying five times daily, fasting, giving to } \\
\text { charity, and pilgrimage to Mecca. }\end{array}$ \\
\hline Jainism & $\begin{array}{l}\text { An early philosophy and moral } \\
\text { teaching that developed in the } \\
\text { seventh-fifth century BCE in } \\
\text { India. }\end{array}$ & $\begin{array}{l}\text { The name was formed from the word 'jina' } \\
\text { which refers to 'victor' or 'liberator' in the } \\
\text { spiritual context. It focuses on achieving } \\
\text { liberation and bliss through living a life of } \\
\text { renunciation and harmlessness. }\end{array}$ \\
\hline Jehovah'sWitnesses & $\begin{array}{l}\text { A } r \text { Christian-oriented } \\
\text { evangelistic religious } \\
\text { movement that originated } \\
\text { around the nineteenth century } \\
\text { in the United States. }\end{array}$ & $\begin{array}{l}\text { The followers of this religion hold many of } \\
\text { the beliefs consistent with the traditional } \\
\text { Christian perspective but also believe in } \\
\text { some that are unique to the religious group. } \\
\text { They believe that Jehovah (God) is the most } \\
\text { high and the Holy Spirit is the active force of } \\
\text { God in this world, while Jesus Christ is the } \\
\text { agent of God who reconciles sinful humans to } \\
\text { God. They also believe that those who accept } \\
\text { Jehovah will be rewarded with membership } \\
\text { of the millennial kingdom, while those who } \\
\text { do not acknowledge him will not go to hell } \\
\text { but become totally exterminated. }\end{array}$ \\
\hline Judaism & $\begin{array}{l}\text { Judaism originated in the } \\
\text { Middle East over } 3,500 \text { years } \\
\text { ago and is about the covenant } \\
\text { relationship of the Jewish } \\
\text { people with God. }\end{array}$ & $\begin{array}{l}\text { It revolves around the belief that there is } \\
\text { only one God who appointed Jews to be his } \\
\text { chosen people to set the example of ethical } \\
\text { behaviour and holiness to the world. Their } \\
\text { religious document is called the Torah and } \\
\text { religious leaders are addressed as Rabbi. }\end{array}$ \\
\hline
\end{tabular}




\begin{tabular}{|c|c|c|}
\hline Religion & Basic description & Further comments \\
\hline Mormonism & $\begin{array}{l}\text { Founded by Joseph Smith in } \\
1830 \mathrm{CE} \text { in the United States. It } \\
\text { is known as the Church of Jesus } \\
\text { Christ of Latter-Day Saints. }\end{array}$ & $\begin{array}{l}\text { The followers of this religion are known } \\
\text { as Mormons and they believe that they } \\
\text { are Christians but with some differences } \\
\text { to mainstream Christianity. They do not } \\
\text { acknowledge the notion of trinity but hold } \\
\text { the view that the Father, Son, and Holy } \\
\text { Ghost are three distinct gods. They believe in } \\
\text { an afterlife and that individuals can become } \\
\text { gods. The Mormons use 'Temple garment', } \\
\text { an underwear with special religious } \\
\text { significance often used by adult members for } \\
\text { hallowed promises to God. }\end{array}$ \\
\hline Paganism & $\begin{array}{l}\text { A topical religious movement } \\
\text { with a philosophical perspective } \\
\text { on reverence for nature. }\end{array}$ & $\begin{array}{l}\text { The focus of Pagans revolves around the } \\
\text { natural world and they worship many deities. } \\
\text { Most of them are eco-friendly thereby } \\
\text { keenly interested in minimising damage to } \\
\text { the natural environment. Some simply define } \\
\text { Paganism as having no specific religion. }\end{array}$ \\
\hline Rastafari & $\begin{array}{l}\text { Originated in the } 1930 \text { s and has } \\
\text { its roots in Jamaica. }\end{array}$ & $\begin{array}{l}\text { It combines mysticism, Protestant } \\
\text { Christianity, and a pan-African political } \\
\text { consciousness. Members, are called Rastas } \\
\text { and most of them believe that Haile Selassie } \\
\text { I, who was crowned the King of Ethiopia } \\
\text { in 1930, is God who came to redeem all } \\
\text { Black people. Part of their religious rituals } \\
\text { are prayer sessions and all-night drumming } \\
\text { ceremonies. }\end{array}$ \\
\hline Santeria & $\begin{array}{l}\text { Afro-Caribbean syncretic } \\
\text { religion that originated from } \\
\text { Cuba. }\end{array}$ & $\begin{array}{l}\text { It is not fixed on a set of beliefs but revolves } \\
\text { around a blend of several faiths and cultures. } \\
\text { It displays a combination of Catholicism, } \\
\text { West African Yoruba spirituality, and } \\
\text { Caribbean tradition. }\end{array}$ \\
\hline Shinto & $\begin{array}{l}\text { Japanese traditional worldview } \\
\text { and ritual with no specific } \\
\text { founder. }\end{array}$ & $\begin{array}{l}\text { Adherents are not expected to follow it as } \\
\text { the only religion. It focuses on the belief that } \\
\text { there are no absolutes as the action taken by } \\
\text { people, whether good or bad, is accessed in } \\
\text { relation to the context in which they take } \\
\text { place. }\end{array}$ \\
\hline
\end{tabular}




\begin{tabular}{|c|c|c|}
\hline Religion & Basic description & Further comments \\
\hline Sikhism & $\begin{array}{l}\text { Founded in the fifteenth century } \\
\text { CE in India by Guru Nanak. }\end{array}$ & $\begin{array}{l}\text { Adherents believe that there is only one } \\
\text { God and equality among humans. They are } \\
\text { focused on avoiding materialism, anger, } \\
\text { covetousness and greed, lust, and pride, but } \\
\text { embrace working, praying, and giving. }\end{array}$ \\
\hline Spiritualism & $\begin{array}{l}\text { Originated in the United States } \\
\text { in the mid-nineteenth century } \\
\text { and Spiritualists hold that it is } \\
\text { possible to communicate with } \\
\text { the dead. }\end{array}$ & $\begin{array}{l}\text { It holds that people survive the deaths of } \\
\text { their bodies and move into a spirit world. } \\
\text { Adherents believe that those who have died } \\
\text { and are in the spirit world have an interest in } \\
\text { the lives of those that are alive. }\end{array}$ \\
\hline Taoism & $\begin{array}{l}\text { Developed from several } \\
\text { religious and philosophical } \\
\text { customs in early China. }\end{array}$ & $\begin{array}{l}\text { Taoism, which is also known as Daoism, has } \\
\text { its philosophical root in nature worship as } \\
\text { well as the divination of Chinese ancestors. It } \\
\text { holds that it is imperative for man to put his } \\
\text { will to be in harmony with nature. }\end{array}$ \\
\hline Unitarianism & $\begin{array}{l}\text { A liberal religious movement } \\
\text { with its origin in the United } \\
\text { States. }\end{array}$ & $\begin{array}{l}\text { Even though it has its origin from Jewish } \\
\text { and Christian practices, it is open-minded to } \\
\text { accommodate insights from other beliefs and } \\
\text { is grounded in rational enquiry as opposed } \\
\text { to external authority. It revolves around } \\
\text { inclusivity and is open to all races, ages, } \\
\text { sexual orientations, and religions. }\end{array}$ \\
\hline Zoroastrianism & $\begin{array}{l}\text { Founded by the Iranian Prophet } \\
\text { Zoroaster. }\end{array}$ & $\begin{array}{l}\text { Adherents believe in the supremacy of God, } \\
\text { called Ahura Mazda, and are traditionally } \\
\text { keen about protecting the natural } \\
\text { environment as they believe that all creations } \\
\text { should be loved and respected. }\end{array}$ \\
\hline
\end{tabular}

Sources: Adapted from BBC (2002, 2009, 2020a, 2020b), Christianity (n.d.), Diamond Day Buddhism (2020), Duchesne-Guillemin (2020), Encyclopaedia.com (2020), Godbey (n.d.), History (2018), McAlister (2020), Melton (n.d.a, n.d.b), MysticalBee (n.d.), Pagan Federation International (n.d.), Shah et al. (nd), SikhNet (n.d.), Unitarians (n.d.), Wigington (2019).

\section{RELIGION AND CONSUMER BEHAVIOUR IN THE TWENTY-FIRST-CENTURY DEVELOPING NATIONS}

Religion plays a key role in how consumers make sense of their purpose in life and responsibilities to themselves, others, and God but the narrative around religion is still considered controversial to an extent (Johnson, 2000; Mansori et al., 2015). It is important for marketers to be sensitive to their values, otherwise actions taken could be deemed offensive and result in a negative impression of the organisation and its brands. As an example, it has been noted that religion has significant implications among Africans with 
traditional religious beliefs playing a potent role in their pattern of day-to-day living and social interactions with various groups (Opoku, 1978; Addai et al., 2013). Its influence permeates virtually every aspect of life such as travelling, farming, eating, and drinking (Addai et al., 2013). The link between religion, trust and relationship marketing has also been established (Al-Abdulrazak and Gbadamosi, 2017). Overall, it is argued that religious affiliation constitutes a key determinant of people's interpersonal trust (Addai et al., 2013). The study of Cornwell et al. (2005), which revolves around cross-cultural study of the role of religion in consumers' ethical position, emphasises the significance of trust. They show that when business organisations participate to foster social integration which also engenders relationship and trust among consumers, these consumers will also exhibit loyalty to those businesses.

Meanwhile, these differences in how religion influences consumption generally emphasise the divide between developing and developed nations which seems to have been disrupted in some way by globalisation in which consumers are becoming increasingly exposed to the cultural values and mores of others through civilisation, immigration, and technological breakthroughs. Sheth (2006) indicates that the globalisation experienced in the twenty-first century is at variance from its first-wave counterpart in the 1800s. In the article 'Clash of Cultures or Fusion of Cultures?', Sheth (2006) argues that contemporary globalisation features a lack of economic growth of affluent countries that are predominantly aging which prompts their economic integration with emerging economies that are notably young. In this contention, it is argued that emerging economies, especially China and India, will rival the developed economies. He cites examples of evidence of such developments as major Western awards won by Indian writers and artists. Consequently, it was projected that this will result in a fusion of cultures rather than a clash of cultures. While this publication is now over a decade old, the current state of affairs in the world economy corroborates this projection. For example, Amine et al. (2012) note that the main actors in modern retailing are now making incursions into emerging nations as these countries offer decent growth prospects and returns on investment which could be attributed to a number of developments such as improvements in gross development product and an increasing middle class. The same argument is made by Rihtaršič and Rihtaršič (2017) who claim that the globalisation, continuous migration of people, and access to information make the boundary between rural and urban populations rather blurred.

The link between religion, religiosity, and consumer behaviour in developing countries remains of keen interest. In a study on religiosity and consumer behaviour, with a specific focus on Muslims in Burkina Faso, Nasse et al. (2019) raise a crucial question on why Muslims, who are expected to be less tolerant of the consumption of alcoholic drinks, are rather begining to consume 
them. They conclude that the notion of religiosity should be taken into consideration by marketers of non-alcoholic drinks in the country.

\section{CONCLUSION}

Consumption activities constitute a key role in defining human systems. Irrespective of categories of life that we belong to, we consume various products and services to 'keep going'. Essentially, this is linked to the fact that these market offerings are designed by various organisations to satisfy needs of different categories. These could be described in a number of ways such as basic, sophisticated, social, personal, cultural, esteem-related, religion-related, and many others. Meanwhile, apart from the fact that consumers' needs are numerous, these needs vary in relation to time and several other contexts such as developed and developing countries. Hence, the nature of products and services consumed several decades ago would most likely be different from what is needed now. Hence, having an understanding of the contemporary consumer behaviour is a worthy endeavour. As there are changes in the nature of the market offerings so will such changes be evident in the process associated with buying them. Fundamentally, extant literature has established that consumption follows a decision-making process which consists of need recognition, search for information, evaluation of alternatives, purchase, and post-purchase evaluation. While the fundamental scholarship efforts establishing this contention date back several decades, there are emerging issues in the dynamics of how consumers move through them. From a very broad perspective, consumers' choices of products and services are influenced by a number of factors that could be categorised as personal, social-cultural, and marketing stimuli. These factors are interrelated in how they influence consumption. Nonetheless, the prominent examples of changes to the consumer decision-making process are the relevance of digital technologies and prominence of religion. Consumers' need for products associated with religions is diverse and continues to grow in line with the multiple religious groups all over the world. Similarly, while searching for information that could help the choice and evaluation of the available options, the role of religion is crucial especially for those with a high level of religiosity. Similarly, the specific choice to buy and the perception of how the object fits personal use are increasingly being tuned by religion. At the stage of post-purchase evaluation when consumers review the decisions to gauge whether the identified needs have been met or not, the relevance of religion in that process could be very significant.

While culture depicts the way and pattern of life of members of a particular society, its close link to religion could be pivotal in the explication of consumption decisions. The link emphasises the logic behind the study of consumption issues and processes in developing nations. The contemporary 
developing nations exhibit some similarities in consumption patterns that mirror those noted for developed nations (Gbadamosi, 2019b). Nonetheless, there are still some useful interesting differences. Arguments in either direction constitute part of the discourse that make the study of consumption intriguing. Adding the twist of religion to this enriches the excitement associated with the subject vis-à-vis the context of developing nations. It has been established that consumers in developing nations tend to be more religious when compared to those in developed societies. Meanwhile, consumers' attachment to their religious beliefs culminates in the trust they have for specific products and brands that ultimately reflects in preferences for such market offerings. Hence, by implication, both local and international marketers have great opportunities in the developing nations as communities with great and diverse needs. As different factors influence consumption, exploring the dynamics of religious beliefs in the strategic planning for businesses could yield handsome returns on investment.

\section{REFERENCES}

Abu-Nimer, M. (2001). Conflict resolution, culture, and religion: Toward a training model of interreligious peacebuilding. Journal of Peace Research, 38(6), 685-704.

Adams, J. S. (1963). Toward an understanding of inequity. Journal of Abnormal and Social Psychology, 67, 422-36.

Addai, I., Opoku-Agyeman, C., \& Ghartey, H. T. (2013). An exploratory study of religion and trust in Ghana. Social Indicators Research, 110(3), 993-1012.

Ahmed, A. (2008). Marketing of halal meat in the United Kingdom: Supermarkets versus local shops. British Food Journal, 110, 655-70.

Aiyede, E. R., Simbine, A. T., Fagge, M. A., \& Olaniyi, R. (2011). Religion, ethics and attitudes toward corruption in Nigeria. Research for Development, 25(1-2), 205-37.

Al-Abdulrazak, R., \& Gbadamosi, A. (2017). Trust, religiosity, and relationship marketing: A conceptual overview of consumer brand loyalty. Society and Business Review, 12(3). DOI: 10.1108/SBR-03-2017-0014.

Alam, S. S., Mohd, R., \& Hisham, B. (2011). Is religiosity an important determinant on Muslim consumer behaviour in Malaysia? Journal of Islamic Marketing, 2(1), $83-96$.

Amine, A., \& Hendaoui Ben Tanfous, F. (2012). Exploring consumers' opposition motives to the modern retailing format in the Tunisian market. International Journal of Retail and Distribution Management, 40(7), 510-27.

Andrews, M., Kinnvall, C., \& Monroe, K. (2015). Narratives of (in)security: Nationhood, culture, religion, and gender: Introduction to the special issue. Political Psychology, 36(2), 141-9.

Arnould, E. J., \& Thompson, C. J. (2005). Consumer culture theory (CCT): Twenty years of research. Journal of Consumer Research, 31(4), 868-82.

Asem, N. R. (2018). Consumer behaviour approach under the aspect of concept evolution. Business and Administration, 366(1), 51-66.

Babin, B. J., \& Harris, E. J. (2018). CB. Boston, MA: Cengage Learning. 
BBC (2002). Pagan beliefs. www.bbc.co.uk/religion/religions/paganism/beliefs/beliefs .shtml (accessed 17 May 2020).

BBC (2009). God, Zoroaster and immortals. www.bbc.co.uk/religion/religions/ zoroastrian/beliefs/god.shtml (accessed 15 May 2020).

BBC (2020a). Ethics in Shinto. www.bbc.co.uk/religion/religions/shinto/shintoethics/ ethics.shtml (accessed 16 May 2020).

BBC (2020b). Islam. www.bbc.co.uk/religion/religions/islam/ataglance/glance.shtml (accessed 15 May 2020).

Chatterjee, S., \& Mandal, P. (2020). Traveler preferences from online reviews: Role of travel goals, class and culture. Tourism Management, 80, 104-8.

Christianity (n.d.). The basics of Christianity. https://christianity.org.uk/the-basics (accessed 28 April 2020).

Cornwell, B., Chi Cui, C., Mitchell, V., Schlegelmilch, B., Dzulkiflee, A., \& Chan, J. (2005). A cross-cultural study of the role of religion in consumers' ethical positions. International Marketing Review, 22(5), 531-46.

Cox, H., Sharma, A., Abe, M., Sachedina A. L., Oberoi, H., \& Idel, M. (1994). World religions and conflict resolution, in D. Johnston \& C. Sampson (eds), Religion: The Missing Dimension of Statecraft. Oxford: Oxford University Press, pp. 266-84.

Dennis, C., Merrilees, B., Jayawardhena, C., \& Tiu Wright, L. (2009). E-consumer behaviour. European Journal of Marketing, 43(9/10), 1121-39.

Diamond Day Buddhism (2020). What is Buddhism? www.diamondway-buddhism .org/buddhism/ (accessed 8 April 2020).

Duchesne-Guillemin, J. (2020). Zoroastrianism: Religion. 17 July. www.britannica .com/topic/Zoroastrianism (accessed 30 July 2020).

Dumbili, E. (2013). Changing patterns of alcohol consumption in Nigeria: An exploration of responsible factors and consequences. Journal of the BSA MedSoc Group, 7(1), 20-33.

Egan, V., \& Taylor, D. (2010). Shoplifting, unethical consumer behaviour, and personality. Personality and Individual Differences, 48(8), 878-83.

Egberongbe, W. (1988). Ifa, the arrow: Pointer to nation - Building, in C. S. Momoh, C. O. Onikpe, \& V. ChukwuDozie (eds), Nigerian Studies in Religion and Tolerance, Lagos: Centre for African and Black Arts Civilization.

Encyclopaedia.com (2020). African traditional religions. Wordmark Encyclopaedia of Religious Practices, 18 June. www.encyclopedia.com/religion/encyclopedias -almanacs-transcripts-and-maps/african-traditional-religions (accessed 8 July 2020).

Gbadamosi, A. (2012). Exploring children, family, and consumption behaviour: Empirical evidence from Nigeria. Thunderbird International Business Review, 54(4), 591-605.

Gbadamosi, A. (2015). Exploring the growing link of ethnic entrepreneurship, markets, and Pentecostalism in London (UK): An empirical study. Society and Business Review, 10(2), 150-69.

Gbadamosi, A. (2019a). Postmodernism, ethnicity, and celebrity culture in women's symbolic consumption. International Journal of Market Research. DOI: $10.1177 / 1470785319868363$.

Gbadamosi, A. (2019b). Women entrepreneurship, religiosity, and value-co-creation with ethnic consumers: Revisiting the paradox. Journal of Strategic Marketing, 27(4), 303-16.

Gbadamosi, A. (2020). Buyer behaviour in the 21st century: Implications for SME marketing, in S. Nwankwo \& A. Gbadamosi (eds), Entrepreneurship Marketing: Principles and Practice of SME Marketing, 2nd ed., Abingdon: Routledge, pp. 72-96. 
Godbey, J. C (n.d.). Unitarianism and universalism. Encyclopaedia Britannica. www .britannica.com/topic/Unitarianism (accessed 17 May 2020).

Hartmann, P., Apaolaza, V., \& D'Souza, C. (2018). The role of psychological empowerment in climate-protective consumer behaviour: An extension of the value-belief-norm framework. European Journal of Marketing, 52(1/2), 392-417.

Harvey, J., Carter, S., \& Mudimu, G. (2000). A comparison of work values and motives among Zimbabwean and British managers. Personnel Review, 29(6), 723-42.

Haynes, J. (2019). Religion, education and security: The United Nations Alliance of Civilisations and Global Citizenship. Religions, 10(1), 51.

History (2018). Mormons. 21 August. www.history.com/topics/religion/mormons (accessed 30 June 2020).

Hordern, J. (2016). Religion and culture. Medicine, 44(10), 589-92.

Hoyer, W. D., MacInnis, D. J., \& Pieters, R. (2018). Consumer Behaviour, 7th ed. Boston, MA: Cengage Learning.

Internet World Stats (2020). Usage and population statistics. www.internetworldstats .com/stats.htm (accessed 8 July 2020).

Jamal, A., \& Sharifuddin, J. (2015). Perceived value and perceived usefulness of halal labelling: The role of religion and culture. Journal of Business Research, 68(5), 933-41.

Johnson, E. L. (2000). Describing the self within redemptive history. Journal of Psychology and Christianity, 19(1), 5-24.

Knowledge Team (2017). What are the characteristics of developing countries. Knowledgiate. www.knowledgiate.com/characteristics-of-developing-countries/ (accessed 8 July 2020).

Kruger, D. P., Gandy, S. K., Bechard, A., Brown, R., \& Williams, D. (2009). Writing a successful Fulbright group projects abroad grant: Voices from a journey to South Africa. Journal of Geography, 108(4-5), 155-62.

Mansori, S., Sambasivan, M., \& Md-Sidin, S. (2015). Acceptance of novel products: The role of religiosity, ethnicity and values. Marketing Intelligence and Planning, 33(1), 39-66.

Maslow, A. H. (1943). A theory of human motivation. Psychological Review, 50, 370-96.

McAlister, E. A. (2020). Rastafari: Political and religious movement. Encyclopaedia Britannica, 23 July. www.britannica.com/topic/Rastafari (accessed 30 July 2020).

McClelland, D. C. (1978). Managing motivation to expand human freedom. American Psychologist, 33(3), 201.

McDaniel, S. W. \& Burnett, J. J. (1990). Consumer religiosity and retail store evaluative criteria. Journal of the Academy of Marketing Science, 18(2), 101-12.

Melton, J. G. (n.d.a). Jehovah's Witness. Encyclopaedia Britannica. www.britannica .com/topic/Jehovahs-Witnesses (accessed 28 April 2020).

Melton, J. G. (n.d.b). Spiritualism: Religion. Encyclopaedia Britannica. www .britannica.com/topic/spiritualism-religion (accessed 17 May 2020).

Mensah, Y. M. (2014). An analysis of the effect of culture and religion on perceived corruption in a global context. Journal of Business Ethics, 121(2), 255-82.

Mokhlis, S. (2006). The effect of religiosity on shopping orientation: An exploratory study in Malaysia. Journal of American Academy of Business, 9(1), 64-74.

Mokhlis, S. (2009). Relevancy and measurement of religiosity in consumer behavior research. International Business Research, 2(3), 75-84.

Mooij, M. D. (2003). Convergence and divergence in consumer behaviour: Implications for global advertising. International Journal of Advertising, 22(2), 183-202. 
Munroe, R. L., \& Munroe, R. H. (1972). Obedience among children in an East African society. Journal of Cross-Cultural Psychology, 3(4), 395-9.

MysticalBee (n.d.). 10 beliefs of Taoism religion. https://mysticalbee.com/beliefs-of -taoism-religion/ (accessed 15 May 2020).

Nasse, T. B., Ouédraogo, A., \& Sall, F. D. (2019). Religiosity and consumer behavior in developing countries: An exploratory study on Muslims in the context of Burkina Faso. African Journal of Business Management, 13(4), 116-27.

Nayeem, T. (2012). Cultural influences on consumer behaviour. International Journal of Business and Management, 7(21), 79-91.

Opoku, K. A. (1978). West African traditional religion. Accra: FEP International Private.

Pagan Federation International (n.d.). What is Paganism. Paganism Federation International. www.paganfederation.org/what-is-paganism/ (accessed 30 June 2020).

Patel, M. (2012). Influence of religion on shopping behaviour of consumers: An exploratory study. Abhinav National Monthly Refereed Journal of Research in Commerce and Management, 1(5), 68-78.

Pokimica, J., Addai, I., \& Takyi, B. K. (2012). Religion and subjective well-being in Ghana. Social Indicators Research, 106(1), 61-79.

Polese, A., \& Seliverstova, O. (2020). Luxury consumption as identity markers in Tallinn: A study of Russian and Estonian everyday identity construction through consumer citizenship. Journal of Consumer Culture, 20(2), 194-215.

Porter, C. A. (2013). The religion of consumption and Christian neighbor love. Doctoral dissertation, Loyola University, Chicago.

Rihtaršič, T., \& Rihtaršič, M. (2017). Model of consumer behaviour: Feminine hygiene. Economics, 5(1), 125-36.

Schiffman, L. G., \& Wisenblit, J. (2019), Consumer Behaviour, 12th ed. Harlow: Pearson Education.

Shah, U. P., Strohl, G. R., \& Dundas, P. (n.d.). Jainism. Encyclopaedia Britannica. www.britannica.com/topic/Jainism/Festivals (accessed 9 July 2020).

Shavitt, S., Lalwani, A. K., Zhang, J., \& Torelli, C. J. (2006). The horizontal/vertical distinction in cross-cultural consumer research. Journal of Counseling Psychology, $16,325-56$.

Shaw, S., Chovancová, M., \& Bejtkovský, J. (2017). Consumer behaviour and warranty claim: A study on Czech consumers. Economics and Sociology, 10(3), 90-101.

Sherif, M. (1966). Common Predicament: Social Psychology of Intergroup Conflict and Cooperation. Boston, MA: Houghton Mifflin.

Sheth, J. N. (2006). Clash of cultures or fusion of cultures? Implications for international business. Journal of International Management, 12(2), 218-21.

SikhNet (n.d.). Who are Sikhs? What is Sikhism? www.sikhnet.com/pages/who-are -sikhs-what-is-sikhism (accessed 16 May 2020).

Singhal, N. (2018). A study of consumer behaviour towards genetically modified foods and the moderating effects of health consciousness. Vision, 22(3), 306-15.

Solomon, M. R. (2018). Consumer Behaviour: Buying, Having, and Being, 12th ed. Harlow: Pearson Education.

Solomon, M. R. (2020). Consumer Behaviour: Buying, Having, and Being, 13th ed. Harlow: Person Education.

Sow, D. M. (2005). Alimentation et boisson au Burkina Faso: au-delà de la survie. Geneva: International Labour Organization. 
Suhrke, A. (1971). Political rituals in developing nations: The case of the Philippines. Journal of Southeast Asian Studies, 2(2), 126-41.

Švecová, J., \& Odehnalová, P. (2019). The determinants of consumer behaviour of students from Brno when purchasing organic food. Review of Economic Perspectives, 19(1), 49-64.

Tajfel, H. (1982a). Social psychology of intergroup relations. Annual Review of Psychology, 33, 1-39.

Tajfel, H. (ed.) (1982b). Social Identity and Intergroup Relations. Cambridge: Cambridge University Press.

Temin, P. (1997). Is it kosher to talk about culture? Journal of Economic History, 57(2), 267-87.

Ting, H., Thaichon, P., Chuah, F., \& Tan, S. R. (2019). Consumer behaviour and disposition decisions: The why and how of smartphone disposition. Journal of Retailing and Consumer Services, 51, 212-20.

UN (2013). World economic situation and prospects 2014: Global economic outlook, December, www.un.org/en/development/desa/publications/wesp2014-firstchapter .html (accessed 8 July 2020).

Unitarians (n.d.). Unitarianism explained. www.unitarian.org.uk/pages/unitarianism -explained (accessed 17 May 2020).

Wigington, P. (2019). What is Santeria? www.learnreligions.com/about-santeria traditions-2562543, 13 February (accessed 3 May 2020).

Winter, B. (2006). Religion, culture and women's human rights: Some general political and theoretical considerations. Women's Studies International Forum, 29(4), 381-93.

World Bank (2020). World Bank Country and Lending Group. https://datahelpdesk .worldbank.org/knowledgebase/articles/906519 (accessed 12 May 2020).

Worthington, E. L., Wade, N. G., Hight, T. L., Ripley, J. S., McCullough, M. E., Berry, J. W. et al. (2003). The religious commitment inventory - 10: Development, refinement and validation of a brief scale for research and counselling. Journal of Counselling Psychology, 50, 84-96.

Yagboyaju, D. A. (2017). Religion, culture and political corruption in Nigeria. Africa's Public Service Delivery and Performance Review, 5(1), 1-10. 